\title{
Beverly Guzman Gallegos's Testimonio
}

\author{
Valerie M. Mendoza
}

This article is the testimonio of Beverly Guzman Gallegos, whose family was one of the named plaintiffs in the Mendez $v$. Westminster case that led to the desegregation of Mexican children in the California schools. Although the Mendez story has been well documented, the contributions of the other named plaintiffs - the Guzman, Ramírez, Palomino, and Estrada families - have yet to be heard. The following testimonio provides a fuller picture of the discrimination pervasive at the time and the heroism of the Guzmans and other Mexican American families of the day. While Gallegos gives a brief testimonio, much can be drawn from it. She reveals the importance of women in the fight against educational segregation, parental agency and resistance, and the pivotal role of community organizing. We also garner similarities between her family's story and that of the other plaintiffs, which restores the parallel version of events to the narrative rather than keeping it focused on one family's story. The testimonio also allows us to consider whose stories we tell and whose are left out; it leads us to ask how our understanding of the case differs once we hear the Guzman story and that of the other plaintiffs.

In June of 2016, I was contacted by Beverly Guzman Gallegos about her family's involvement with the Mendez v. Westminster (1947) case. For several years she spoke at local events, but she wanted a wider venue for her story. A friend told her about the special issue of American Studies that I was coediting with Norma E. Cantú and gave her my contact information. We discussed hav- 
ing her write her story, my being a coauthor on an article with her, my writing an interview with her, but we ultimately settled on the testimonio format. We wanted to preserve her voice and give an accounting of her family's history of discrimination in the Orange County schools. Her brother, Billy (who is deceased), was a minor plaintiff in the case brought forth by her father William Guzman. Her family's story remains untold until now.

The following testimonio gives a fuller picture of the discrimination pervasive at the time and the heroism of the Guzmans and other Mexican American families of the day. The testimonio also makes us consider whose stories we tell and whose are left out; it leads us to ask, how does our understanding of the case differ once we hear the Guzman story and that of the other plaintiffs? For example, Gallegos's testimonio reveals strategies of resistance used by her family to combat segregation. ${ }^{1}$ What follows is her testimony of events leading up to and following the historic court case that desegregated schools in California. Prior to telling her story, I provide historical background on the case, including treatment of Mexicans and Mexican Americans prior to 1950 in Southern California.

Mendez v. Westminster received little attention, even within law circles, and was all but forgotten for decades. Not until 1998, when Santa Ana school district named its new middle school after Gonzalo and Felicitas Mendez, did this little-known piece of history resurface. Yet, when the case finally received widespread attention, scholars chronicled it exclusively through the eyes of the namesake Mendez family and minor plaintiff Sylvia Mendez and virtually erased the community-wide effort to combat segregation in the schools - particularly those efforts of the other named plaintiffs. An award-winning 2002 documentary, Mendez v. Westminster: For All the Children, produced by Sandra Robbie; the leading law book on the case written in 2010 by Philippa Strum; and a children's picture book by Duncan Tonatiuh published in 2014 all center on the story of the Mendez family or Sylvia Mendez and barely mention the other named plaintiffs. ${ }^{2}$ The index to Strum's book lists one reference to plaintiff Thomas Estrada, two for Lorenzo Ramirez, four for Frank Palomino, and four for William Guzman. No references are made to the wives or children of these plaintiffs. By contrast, Strumm's index cites thirty pages referring to Gonzalo Mendez, nineteen to his wife Felícitas, eight to his daughter Sylvia, and four to his son Gonzalo Jr. ${ }^{3}$ Additionally, it was only Sylvia Mendez who was awarded the Presidential Medal of Freedom in 2011 for her role in the case. The exception to this apparent post-1998 erasure is two articles written years apart in the $O C$ Weekly by Gustavo Arellano. ${ }^{4}$ In these articles Arellano questions the telling of the case from the Mendez point of view. In fact, one of the articles focuses on the Ramírez family. This testimonio adds to Arellano's efforts to generate a fuller understanding of the case. 


\section{Mendez v. Westminster}

Briefly, Mendez v. Westminster was a class action lawsuit filed in federal court by five families of Mexican heritage on behalf of over five thousand Mexican and Mexican American children in Orange County, California, covering four school districts. The Mendez and Thomas Estrada families represented the Westminster district; the Guzmans, Santa Ana; the Frank Palomino family, Garden Grove; and Lorenzo Ramirez and his family, El Modena. The plaintiffs argued that their Fourteenth Amendment rights to equal protection under the law were being violated by Orange County school districts in the cities of Santa Ana, Westminster, Garden Grove, and El Modena because these school districts forced Mexican and Mexican American children to attend separate schools based solely on the fact that they were of Mexican descent.

By 1934, Mexican or Mexican Americans comprised 25 percent of the Orange County student population, and 70 percent of these children attended schools with 100 percent Mexican enrollment. ${ }^{5}$ The case did not argue racial discrimination, nor was it argued in California courts based on California law, which allowed for the segregation of Indian and Chinese children, but rather it went before a federal court. The attorney for the plaintiffs, David Marcus, reasoned that if he argued the case on the basis of California laws, the law could be changed and Mexican children would remain segregated. ${ }^{6}$ In his petition to the court, Marcus wrote that his clients were deprived of their civil rights as granted them by the Constitution because the named school districts denied them access to schools based on their "Mexican or Latin descent or extraction." In other words, the school districts segregated the students based on their ethnicity, and Marcus showed this systemic discrimination throughout the trial. The school board itself claimed that they did not separate Mexican children based on race, but rather that they placed Mexican children in a school different from that for Anglo children due to pedagogical reasons. The school districts claimed that Mexican children hindered the learning of white children due to language deficiency. ${ }^{8}$ The school board maintained this policy even though schools administered no language tests. Principals automatically sent children with Mexican surnames to separate schools. In fact, the attorney for the plaintiffs presented his case so effectively that when the presiding judge handed down his decision, it was a resounding victory. The judge, Paul McCormick, ruled that segregation was "illegitimate as a matter of both California and federal constitutional law." The plaintiffs appealed the decision to the Ninth Circuit Court; the ruling was upheld, causing the school districts to integrate their schools. ${ }^{10}$

\section{Background on Discrimination against Mexicans and Mexican Americans in California}

California and many other southwestern states racialized Mexicans and Mexican Americans since their lands were acquired from Mexico following 
the Mexican-American War in the mid-nineteenth century. ${ }^{11}$ Anglo Americans usurped the property of Mexicans by squatting on private property, took control of local governments, and systematically deprived Mexicans of their rights as citizens once California became a state. ${ }^{12}$ Years later, thousands of migrants from Mexico flocked to the United States during the first two decades of the twentieth century because of economic hardship and political upheaval caused by the Mexican Revolution, drastically increasing the Mexican population in California. These newcomers settled in their own enclaves and often became targets of discrimination. For example, restaurants refused them service, public pools did not allow them to swim there except on certain days, and movie theaters forced them to sit in separate areas away from Anglo patrons. ${ }^{13}$

Antipathy toward Mexicans and Mexican Americans intensified during the World War II years. The Los Angeles Times castigated Mexican youth as hoodlums and gang members. Several Mexican young men were tried in the court of public opinion in 1942 in what became known as the Sleepy Lagoon Murder. Police rounded up hundreds of Mexican youth for suspicion of killing José Díaz in a clear case of racial profiling. The courts eventually convicted seventeen based on inadequate counsel and circumstantial evidence. ${ }^{14}$ Headlines such as "Haircuts Used in Identification of Hoodlums: Suspects Must Not Change Haircuts, Judge Rules" influenced public opinion against Mexican youth and revealed a biased judicial system. ${ }^{15}$ In yet another instance of racial profiling, just a year later, Anglo servicemen hunted down and beat any Mexicans they saw wearing the notorious zoot suit ${ }^{16}$ over several days in what the local papers dubbed the Zoot Suit Riots. The area press used biased language in reporting this event as well by referring to the Mexican Americans attacked as gang members and hoodlums despite no evidence to support such claims. In addition, police arrested Mexican victims who were assaulted rather than Anglo sailors who perpetrated the violence. Not until the Navy rescinded shore leave for sailors did the violence subside. ${ }^{17}$

\section{School Discrimination}

California school districts also discriminated against Mexican children well before the Westminster case. For example, in San Diego County, Roberto Alvarez sued the Lemon Grove school district in 1931. This was the first successful lawsuit to challenge school segregation and was even more important because it occurred at a time when many communities such as Los Angeles deported Mexicans and Mexican Americans. ${ }^{18}$ This case, however, was tried in the California courts, not the federal courts, and was therefore not as far reaching. It also alleged segregation and discrimination based on race but did not use the Fourteenth Amendment argument used in the Mendez.

School districts throughout the country practiced segregating Mexican students outside of the law. They placed Mexican students in separate classrooms or else used old, rundown schools once new ones were built for white students. 
School officials often defended these policies as necessary due to pedagogical reasons-lack of English language proficiency on the part of Mexican-origin students - but more often than not community pressure was the cause. ${ }^{19}$

So-called "Mexican" schools also tracked students into vocational classes in order to maintain a Mexican labor force.$^{20}$ For example, schools taught Mexican girls homemaking skills for their presumed future roles as domestics. ${ }^{21}$ School boards throughout the county intentionally "created a system to meet the labor needs of local ranchers, particularly in the case of El Modena."22

This type of segregation was not limited to Orange County. Mexican parents in other parts of the country actively resisted school segregation as well. For example, in Kansas City, Kansas, during the mid-1920s, parents kept children at home rather than send them to segregated schools. ${ }^{23}$ In Texas, parents of Mexican and Mexican American children began using the courts in 1930 in attempts to combat segregation. ${ }^{24}$

\section{Common Retelling of the Mendez Case}

The standard narrative of the Mendez case begins in September 1943 with Gonzalo Mendez's sister, Soledad Vidaurri, escorting her two children, nephew Gonzalo Jr. and niece Sylvia, to enroll at the Westminster elementary school. ${ }^{25}$ The principal accepts the two light-skinned Vidaurri sisters but refuses to enroll the Mendez siblings who had darker complexions. Mrs. Vidaurri questions the principal as to his reasoning and is told by him that school policy dictates that Mexican children be enrolled at the Mexican school. Mrs. Vidaurri refuses to enroll her children, returns home, and relates the situation to her brother. Gonzalo storms off to talk to the principal who tells him that the school board set the policy for a separate school for Mexicans, and Gonzalo takes his complaint to the school board who does nothing. At this point Mendez is so incensed at the inequality of the situation that he hires a lawyer, David Marcus, ${ }^{26}$ who advises him that his case would be stronger if he recruited other Mexican parents to establish a pattern of systemic discrimination. Gonzalo leaves the farm to be run by his wife and traipses all over the county going door to door to recruit parents to join the lawsuit. ${ }^{27}$

Although the Mendez story has been well documented, the contributions and stories of the other named plaintiffs - the Guzman, Ramirez, Palomino, and Estrada families - have yet to be heard. This article captures Beverly Gallegos's testimony in order to begin to rectify this omission. Her testimonio opens the dialogue, the narrative, and the history of the case through the voice of one woman seeking to tell her family's story. ${ }^{28}$ It represents a tribute to William and Virginia Guzman, their son Billy, and the entire Guzman family. 


\section{Beverly Guzman's Testimonio ${ }^{29}$}

"My father was William Guzman. He worked for Consolidated Air in San Diego during WW II while the family remained in Santa Ana. My brother Billy entered kindergarten at Fremont Elementary School in Santa Ana in 1942. My parents then tried to enroll him in Franklin Elementary (all-white school) the following year, but he was turned away because he was Mexican and had a Spanish surname. In addition, the school board gerrymandered the school district lines forcing Mexicans to attend Fremont by saying we lived within the Fremont boundaries. We lived closer to Franklin, and my mom wanted Billy to attend this school because it was more convenient for her to walk him to and from school. Franklin was also the better school. It had newer text books, a playground with equipment, and offered hot lunches. My father, who possessed a strong sense of right and wrong, complained to the principal who said that it was a decision of the school board to have separate schools. My dad then went to the school board to denounce the policy. ${ }^{30}$

"When the school board didn't listen, and did nothing, Dad brought in an attorney, Charles Martin, to the school board meeting. He was the first plaintiff to hire an attorney. In fact, my father's attorney, Mr. Martin, drew up the letter that Mr. Mendez initially took to the Westminster school board before hiring Mr. Marcus. The school board didn't like that my father hired an attorney and offered for Billy to attend Franklin if my dad looked the other way and not let the other Mexican parents know. My parents refused and kept Billy out of school for an entire year until the new, private Catholic school called St. Anne's opened. My brother's best friend Norman, who was white, attended Franklin during this time, and my brother didn't understand why he couldn't go to school there as well. My brother was traumatized by being left out and never talked about school or the trial except to mention the kindness Arthur Palomino, another minor plaintiff, showed to him during the trial.

"After the flap with the school board, my dad took a job closer to home and began working at Veiga Mortuary. Mr. Veiga was involved with an organization in Santa Ana that preceded LULAC. ${ }^{31}$ I believe it was called the Latin American Association. ${ }^{32} \mathrm{He}$ and Mr. Palomino (who was my dad's best friend) began to meet with Mr. Veiga and others to discuss all sorts of problems that Mexican Americans in the area experienced. As part of these meetings, the issue of segregation in the schools came out. Dad knew Mr. Mendez because they lived in the same neighborhood before Mr. Mendez left Santa Ana to farm in Westminster, and this is how he became involved in the lawsuit. ${ }^{33}$

"My dad was born in the United States along with Mr. Palomino who lived in Garden Grove. Mr. Ramirez, who lived in El Modena, was not a citizen (although his children were) and was represented by the Mexican consulate. Mr. Mendez was a naturalized citizen.

"My father did not need to come forward in the case because he had already decided to send Billy to St. Anne's, a private Catholic school that was 
mostly white, with a few Mexicans. As I said, he had a strong sense of right and wrong and was well liked in the community. Santa Ana was the largest town and the largest school district to be represented in the lawsuit, so he decided to join because the Santa Ana district needed to be represented. My parents went door to door in the neighborhood with my brother Billy to ask for signatures for the petition of the lawsuit. People slammed doors in their faces. Our neighbors did not want to be involved either because they did not have children going to school or because they were not citizens and did not want to have attention drawn to them, but my parents convinced a number to join.

"Several of the families sponsored fund-raisers to pay for the filing fees and attorney fees to hire Mr. Marcus, such as dances at the American Legion in Santa Ana and food sales. Every family paid their own filing fee. The Mendez's did not pay for everything as has been alleged. In addition, Mr. Mendez found the lawyer Marcus with the aid of the Mexican community, who knew of him. ${ }^{34}$

"Both of my parents testified at the trial. In fact, my father lost his temper. The attorney for the defendant tried to discredit Billy and say that the reason he was not allowed to enter Franklin was because his grades were not good enough. This was not true.

"After the case, Billy remained enrolled in St. Anne's, and I and my other brothers also attended private Catholic schools. My dad was treated like a superstar. Everyone knew who he was, and he received a lot of community recognition. My father always talked about the case. He knew its importance and carried a newspaper clipping about it in his wallet that was there the day he died decades later. He was proud to be able to do something.

"I'm sharing my story because about fourteen years ago I attended an event in honor of the case. I was there representing my family, but did not speak. A little girl about ten years old came up to me afterward and said, 'I see all these things your parents have done; what are you going to do?' That got me thinking, and from then on I decided to speak up and share my family's experience to give a fuller picture of events leading up to the trial. I want others to know that Mexican people did things to make a difference too. My parents and the other families endured a long struggle, and it was hard for them."

\section{Conclusion}

While Gallegos gives a brief testimonio, much can be drawn from it. She reveals the importance of women in the fight against educational segregation, parental agency and resistance, and the importance of community organizing. She also reveals similarities between her family's story and those of the other plaintiffs, which restores the parallel version of events to the narrative.

First, Gallegos reveals that her mother initially wanted Billy enrolled in Franklin for convenience. ${ }^{35}$ Franklin was several blocks closer to the Guzman home, which would have saved Virginia Guzman time walking Billy to and from school. This is just one example of the important role women played in 
the fight against segregation. As Gallegos also notes, food sales raised money to pay for the trial and the lawyer. ${ }^{36}$ Historian Gilbert Gonzalez noted in his work that "Mrs. Leonides Sanchez and Mrs. Frank Garcia" appeared before the Santa Ana school board requesting their children be enrolled in Franklin in October 1943, and when their request was denied, sent them to Franklin anyway! ${ }^{37}$ In Santa Ana, therefore, women played a crucial role in bringing segregation to community attention. As lawyer Christopher Arriola noted in his analysis of the case, "Mothers worked hard to get more people involved." 38 Additionally, both men and women made it a point to travel to Los Angeles every day in support of the trial. ${ }^{39}$

Second, her testimonio powerfully shows parental agency and resistance with regard to the segregation of their children. Indeed, Gallegos relates how her parents kept Billy out of school for an entire year rather than send him to a segregated school, and when he returned to school, it was at an integrated private school. The Guzmans did not want their son to endure the humiliation of a segregated institution. As Gallegos notes, her father possessed a strong sense of right and wrong. At a time when patriotism reached its zenith due to US involvement in World War II, her father demanded all the rights due to him and his son as citizens of this country.

Gallegos also stresses the importance of community organization in the charge against segregation. She notes how all families participated in fundraising activities and paying legal fees. She also mentions the leadership of business owner Manuel Veiga and the leadership of the local Mexican American community organization. ${ }^{40}$ Other scholars corroborate Gallegos's assertions by noting that the lawsuit "was truly a community effort that involved a large number of persons from El Modena and the other three cities in the case." ${ }^{\prime 1}$

Finally, Gallegos's testimony reveals parallel events happening in cities across Orange County. For example, the school principals at the white schools in all four cities cited school board policy and lack of English skills as a reason for segregation. The Guzmans also went door to door to drum up family support for the lawsuit efforts in much the same manner as the Mendez family in Westminster and the Ramirez family in El Modena. ${ }^{42}$ These parallel events and commonalities reinforce the importance of telling all the stories in the Mendez $v$ Westminster case. This testimonio of Beverly Guzman Gallegos helps to paint a fuller picture of the case, events leading up to the case, and the impact of Mendez v. Westminster

\section{Notes}

1. I initiated a conversation with her via phone and found the story so compelling that I asked if we could speak again to collaborate on the following testimonio for publication. Eager for her family's contribution to this important piece of segregation history to be acknowledged, she readily agreed. We spoke again (by phone) on August 2 and August 19, and with her permission I recorded the conversations. I am honored to play a small role in telling this story.

2. Sandra Robbie, Mendez v Westminster: For All the Children (Arlington, VA: PBS Learning Media, 2002), DVD; Philippa Strum, Mendez v. Westminster: School Desegregation and 


\section{Beverly Guzman Gallegos's Testimonio 61}

Mexican-American Rights (Lawrence, KS: University Press of Kansas, 2010); Duncan Tonatiuh, Separate Is Never Equal: Sylvia Mendez and Her Family's Fight for Desegregation (New York: Abrams Books for Young Readers, 2014).

3. Strum, Mendez v. Westminster, 182-85.

4. Gustavo Arellano, "OC's Famous Historical Case Finally Gets Its Due, but One Family Feels Left Out," OCWeekly, November 5, 2009, www.ocweekly.com/news/ocs-famous-desegregation-case-finally-gets-its-historical-due-but-one-family-feels-left-out-6431272; Gustavo Arellano, "OC's Famous Desegregation Case Mendez et al v. Westminster et al Celebrates 70 Years This Week," OCWeekly, February 16, 2016, http://www.ocweekly.com/news/ocs-famous-desegregation-case-mendez-et-al-vs-westminster-et-al-celebrates-70-years-this-week-6976134.

5. Philippa Strum, "We Always Tell Our Children They Are Americans': Mendez v. Westminster and the Beginning of the End of School Segregation," Journal of Supreme Court History 39, (2014): 307-328. DOI: 10.1111/j.1540-5818.2014.12051.x.

6. The plaintiffs hired David Marcus of Los Angeles. Marcus counted the Los Angeles and San Diego Mexican consulates as clients and was married to a woman of Mexican descent. Strum, Mendez v. Westminster, 38.

7. Strum, "We Always Tell Our Children They Are Americans,"” 316.

8. A similar case, Hernandez v. Driscoll Consolidated School District (1957) was argued in Texas. The documentary, Stolen Education (2014) tells the story of this case and its aftermath.

9. Strum, "We Always Tell Our Children They Are Americans," 319.

10. The Ninth Circuit Court upheld the decision in April 1947.

11. Kelly Lytle Hernandez, Migra! A History of the United States Border Patrol.

12. Albert Camarillo, Chicanos in a Changing Society (Dallas, TX: Southern Methodist University, 2005)

13. Attorney for the plaintiffs, David Marcus, had successfully tried a case challenging the segregation of the public pool in nearby San Bernadino. Strum, Mendez v. Westminster, 38; see also Gallegos interview with the author, August 2, 2016. Christopher Arriola refers to this as "silent segregation" in his article, "Knocking on the Schoolhouse Door: Mendez v Westminster, Equal Protection, Public Education, and Mexican Americans in the 1940s," La Raza Law Journal 166 (1995): 166-207, http://scholarship.law.berkeley.edu/blrlj/vol8/iss2/2. He postulates that in Orange County segregation developed as a by-product of a stratified citrus society where Mexicans were seen exclusively as laborers. According to Arriola, most Mexicans "were resigned to the system or were silenced by it." Ibid., 167.

14. Eduardo Pagán, Murder at the Sleepy Lagoon: Zoot Suits, Race, and Riot in Wartime L.A. (Chapel Hill, NC: University of North Carolina Press, 2003).

15. "Haircuts Used in Identification of Hoodlums: Suspects Must Not Change Haircuts, Judge Rules," Los Angeles Times, October 27, 1942.

16. Zoot suits were a trademark of certain sectors of Mexican American youth. The outfit consisted of a long coat down to the knees and baggy pants. Many thought the suit an affront to war efforts to conserve fabric.

17. Los Angeles Examiner, June 8, 1943, June 10, 1943. See also Strum, Mendez v. Westminster, who gives a nice background of racial tension in Southern California

18. Robert Alvarez Jr., "The Lemon Grove Incident," Journal of San Diego History 32, no. 2 (1986), http://www.sandiegohistory.org/journal/1986/april/lemongrove; Francisco E. Balderrama and Raymond Rodriguez, Decade of Betrayal: Mexican Repatriation in the 1930s (Albuquerque, NM: University of New Mexico Press, 1995).

19. Charles Wollenberg, "Mendez v. Westminster: Race, Nationality and Segregation in California Schools," California Historical Quarterly 53, no. 4 (1974): 317-32, 361.

20. Arriola, "Knocking on the Schoolhouse Door," 174.

21. Gilbert Gonzalez, "Segregation of Mexican Children in a Southern California City: The Legacy of Expansionism and the American Southwest," Western Historical Quarterly, 16 (1985): 55-76, http://www.jstor.org/stable/968157, 59.

22. Arriola, "Knocking on the Schoolhouse Door," 181.

23. In Kansas City, courts were not used. Rather, Mexican parents protesting the segregation of their children appealed to the Mexican consulate for redress. For an excellent discussion of the segregation of Mexican children in Kansas City see Robert Cleary, "The Education of Mexican Americans in Kansas City, Kansas, 1916-1951" (master's thesis, University of Missouri, 2002).

24. Cynthia E. Orozco, "Del Rio ISD v Salvatierra" in Handbook of Texas Online (Austin, TX: Texas State Historical Association, 1930), https://tshaonline.org/handbook/online/articles/ jrd02.

25. This narrative seems to have begun with Robbies's documentary in 2002. Robbie, Mendez v. Westminster: For All the Children.

26. Marcus himself was the son of immigrants and married to an immigrant from Mexico and had Mexican American children; Philippa Strum, "We Always Tell Our Children They Are Americans," xxx.

27. Strum, Mendez v. Westminster, 1. 
28. Gloria Gonzales Barragan, "Testimonios From the Border: Shattering the Notion That Women Don't Do Theory" (Ed.D. dissertation, University of Massachusetts, Amherst, 2014), vii.

29. Beverly was born in Santa Ana the only girl in a family of five children. She arrived after the ruling of the trial, but has vivid memories of her father discussing it, and her life was affected by the trial. For instance, during and after the trial her parents decided that their children would attend integrated Catholic elementary schools rather than the public schools. She also remembers her brother's friendship with his best friend, Norman, who was white and allowed to go to the allwhite Franklin school. She is also writing a children's story in honor of her brother's experiences as a child during the time of the trial called Billy and the Freemont Dragon. Beverly cared for her brother Roger, her father, and now her mother during their long illnesses. Her father instilled in Beverly a sense of family and justice from an early age.

30. This occurred in October 1944. See Gonzalez, "Segregation of Mexican Children."

31. League of United Latin American Citizens founded in Corpus Christi, Texas, in 1929.

32. She is referring to the Latin American Voter's League. See Gonzales, "Placing the et al. Back in Mendez v. Westminster," this volume.

33. The two lived in the same neighborhood in Santa Ana.

34. Journalist Gustavo Arellano cites a case in Fullerton in 1943 where Marcus represented a Mexican defendant sued by his white neighbors and was therefore known to plaintiff Lorenzo Ramirez, "OC's Famous Desegregation Case," 2016, and Wollenberg states that LULAC members helped to find him, Mendez v. Westminster, 365.

35. According to court transcripts, Franklin (white) school was five blocks from the Guzman home while Fremont (Mexican) school was nine blocks away. Mendez v. Westminster (1946) transcript, Mendez v. Westminster, accessed March 10, 2017, mendezetalvwestminster.com.

36. For the importance of women in the case, see Nadine Bermudez, "Reinscribing History: Mendez et al. $v$ Westminster et al. from the Standpoint of Mexican Origin Women," this volume.

37. Gonzalez, "Segregation of Mexican Children," 69.

38. Arriola, "Knocking on the Schoolhouse Door," 186.

39. Ibid.

40. For more on this, see Gonzales, this volume.

41. Arriola, "Knocking on the Schoolhouse Door," 185.

42. Ibid., 183-84. 